\title{
The Validity of Patois: An analysis on the Linguistic and Cultural aspects of
}

Jamaican Patois

Adriana Williams

The purpose of this essay is to debunk the dated Eurocentric notions that dismiss the significance of Jamaican Patois and to argue the validity of the language. To achieve this, research was conducted by exploring various Caribbean literary and linguistic components of the language. However, for the sake of space, only one example per category was analyzed.

Patois (also known as Jamaican Creole) is the word used to describe Caribbean speech. Patois, or Patois-based languages, are a part of a continuum of creolized languages (Davidson and Schwartz 48), ranging from pidgins and dialects to full languages. Through socialization and systemization over time, [Jamaican] Patois has developed into a language all its own.

However, not all view Patois as a language. One argument is that Patois is a dialect or a pidgin, instead. Neither of these linguistic categories is considered a true language, according to Anglophone standards. Historically, Patois-based languages have been stigmatized for including only some parts of their European lexifiers - or the foundation of a mixed language (Davidson and Schwartz 48) -, hence the common phrase, "broken English."

It is only recently that Creoles such as Patois have started to be sufficiently researched. The result is a growing body of evidence demonstrating that Patois-based languages - which are based on, but deviate from, English - are indeed true languages, and have seen increasing systemization. I argue that Jamaican Patois is indeed a language, comprising of multiple linguistic components. These components build up the strength of the identity of [Jamaican] Patois itself. Furthermore, Patois has contributed to the identity of Jamaica by reproducing black autonomy through the use of Patois. This is evident in Caribbean literature, from poetry to academic prose. To uphold the validity of Patois, linguistic components of the language and the cultural impact of Patois in Jamaica will be analyzed.

Some linguists argue that [Jamaican] Patois is not a language because of its creolized origins. Within the discipline of linguistics, Creoles refer to a speech form that is comprised of two base languages. In fact, the word creole is synonymous with pidgins and dialects, forms of speech that are not languages. Nevertheless, recent investigations have led linguists to confirm that Patois has systemized components, thus separating it from standard English. There are many parts that classify a set speech as a language. For the sake of space, only the syntax (word order) of Patois will be explored in this essay.

For example, similarly to Standard English (or SE), Patois has an SVO (Sentence Verb Object) structure. One finds an example of SVO structure in the following sentence: "Keiti (S) waan (V) wan neda buk (O)," which translates to "Katie wants another book" in SE (Durrelman-Tame 12). This makes up the general structure of sentences in Patois.

In addition, there are variations of grammar that can change the meaning or makeup of a sentence. An example is Verb Duplication (Durrelman-Tame 12). A way of creating emphasis when speaking, a verb can be repeated within a sentence. An example is "a wok 'im 
Adriana WIlliams

The Validity of Patois

a wok," which means "what s/he is doing is working" (Durrelman-Tame 12).

Another example of varying factors in sentence structure is the use of tense in Patois. To convey that an action took place in the past, the words "ehm" or "did" are used as auxiliary verbs. One of these auxiliaries is normally inserted in between the subject and the verb of a sentence: " "im ehn/did nyam it aaf," which means "s/he ate it up" (Durrelman-Tame 12). Categories such as syntax, phonetics (sound patterns), semantics (word meaning), morphology (structure of words) and orthography (spelling) are a part of the many components that make up a language. For Patois to not be a language, it would have to be lacking some of these parts. As stated above, considering how many patterns have been identified within the language, Patois is a functional language, one in which each element within the grammar has purpose and order. Research shows that Patois has a complex linguistic system. These conclusions, however, are evidently held back by dated views of the language that stem back to $17^{\text {th }}$-century Britishoccupied Jamaica and survive the present.

A major factor that has contributed to the idea of Patois being a non-standard language is the cultural stigma associated with the language category. This stigma is reinforced by two different groups: colonialists and Jamaica's own citizens. Firstly, it stems from colonialists who belittled the language. From slavery to independence in 1962, anything that broke with the white norm was deemed inferior by British standards. Even though this language is still connected to English, which acts as its lexifier, it is held in contempt because it comes from slaves who began to make the colonial language their own, through the creolization of English with different African languages (Davidson and Schwartz 48). In turn, the second wave of cultural stigma came from Jamaicans themselves. Due to the conditioning about their own language, repeatedly having it reduced to nothing more than "broken English," Jamaicans have internalized the negative attitudes toward the language. Patois has traditionally been seen as reflecting the the humble socio-economic status of its speakers. Its use can is often labelled as improper and inferior, while also associating a speaker to poverty or a lower class (Bengoechea 78). This is part of an attempt by colonial powers to condition how Jamaicans view their Blackness and culture.

Despite the Eurocentric biases against Patois, it has continually been reproduced in Jamaican society. It is a part of the country's identity and reclamation of Blackness through the use of the language. It can be seen through use across various sectors, such as academia, music, film and writing. An example of Jamaican literature that utilized Patois was written by Louise Bennett-Coverley, better known as Miss Lou. Born in 1919, Miss Lou, a comedienne, writer, and language advocate, was known as one of Jamaica's most important writers. Combing comedy and insight, her work highlighted the importance of valuing African elements in Jamaican culture (Morris), hence the deliberate use of Patois. In addition, she was one of the first to transcribe Patois in written form throughout her work (Otto 105). A famous example by Miss Lou is called Jamaica Labrish. Published in 1966, it is a collection of short poems. The word Labrish means 'gossip' in Patois. Jamaica Labrish was well known for being distinctly written in Patois and being a depiction of everyday life in Jamaica. An example of the use of Patois in Jamaican Labrish is a poem called Duty Bound (Morris). This poem marked the departure of Governor Hugh Foot and Lady Foot, whom Jamaicans adored, 
from the country.

The following is a small excerpt from Duty Bound: "From de day Foots set foot yah, Govanah and Lady start. Fe timely-timely stir demself, eena Jamaica heart" (Morris). This piece plays with irony by using Patois to describe an event revolving around the British. Duty Bound also is important to the idea of experience. This moment in time is a reflection of the Jamaican perspective, and what makes it a uniquely Jamaican experience is the use of Patois, describing it in Jamaica's mother tongue.

Pieces like Duty Bound are prime examples of why the use of Patois is important. Firstly, it demonstrates representation. Duty Bound is one of many descriptions of everyday chatter that Jamaicans took part in. Secondly, it demonstrates resistance. Despite bring streamlined into British systems, Jamaicans have fought against Eurocentric norms through the use of Patois. Using the language in its own right is a message that one's Caribbean-ness is good enough.

Finally, it represents identity. Patois is a part of what it means to be Jamaican. One example is the relationship between creolization and Jamaica. The constant intermingling of different parts of culture and thought, like Patois, is a characteristic of the Caribbean. Literature that uses Patois is also an act of reclamation, which can be seen in different forms. One example is amongst Caribbean women. Audre Lorde once said that "poetry is not a luxury, it is a vital necessity of our existence" (Lorde). Creating literature like poetry is a means of documenting experience and taking back one's voice. In Miss Lou's case, she was documenting the Jamaican experience from a female perspective. Another example is the reclamation of Blackness/Caribbean-ness. The use of Patois focuses on the African heritage of the Caribbean (Brathwaite). Using Patois is a way of connecting with our African roots.

The reproduction of Patois in literature and the refinement of the language represent its longevity. Despite many attempts to replace this language through "Colonial structures" (Morris), it still is widely spoken throughout the country. Without it, Jamaicans would speak primarily Standard English, and in a Jamaican context, Standard English is a language that represents division and oppression. It is important to continue validating Patois as it carries as much value and merit as any other widely studied language. Patois must be upheld by community members as it is a large part of Jamaican identity. Patois in itself represents the history of Jamaica and the efforts to liberate its people, using self-made tools. 
Adriana WIlliams

The Validity of Patois

\section{Works Cited}

Brathwaite, Kamau. History of the Voice: the Development of Nation Language in Anglophone Caribbean Poetry. New Beacon Books, 2011.

Davidson, Cecilia, and Richard G Schwartz. "Semantic Boundaries in the Lexicon: Examples From Jamaican Patois." Linguistics and Education, 1994, pp. 47-64.

Durrleman-Tame, Stephanie. The Syntax of Jamaican Creole: a Cartographic Perspective. John Benjamins, 2008.

Lorde, Audre. "Poetry Is Not a Luxury." Black Women Writers, Alexander Street Press, 1984, https://lit-alexanderstreet-com.myaccess.library.utoronto.ca/blww/view/1000060646.

Morris, Mervyn. Miss Lou: Louise Bennett and Jamaican Culture. Signal Books, 2014.

Otto, Melanie. "The Caribbean." The Routledge Companion to Postcolonial Studies , Routledge, 2007, pp. 95-107.

Universidad de Alcalá de Henares, Bengoechea, Mercedes. Poetry in Patois: Applying a Sociopsychological Approach to the Analysis and Interpretation of British AfroCaribbean Poems. 1997, pp. 77-105, Poetry in Patois: Applying a Sociopsychological Approach to the Analysis and Interpretation of British Afro-Caribbean Poems. 